\title{
A case of refractory multiple myeloma
}

\author{
Ritesh Vekariya ${ }^{a}$, Vishal Satadiya ${ }^{a}$, Manish Bavaliya ${ }^{a}$, Shyam Shah ${ }^{b}$,*
}

${ }^{a}$ Department of Medicine, C.U. Shah Medical College and Hospital, Surendranagar 363001, India, ${ }^{\mathrm{b}}$ Third M.B.B.S., C.U. Shah Medical College and Hospital, Surendranagar 363001, India

Received: 9 August 2012

Accepted: 13 August 2012

*Correspondence to:

Shyam Shah,

Email: shyamshah1308@gmail.com

\begin{abstract}
Multiple myeloma is a plasma cell cancer in which antibody-producing plasma cells grow in an uncontrolled and invasive way. The known incidence of multiple myeloma in India ranges from 0.5 to 1.2 per $100,000 \&$ is a rare in India. It usually occurs in persons older than 55 years and the ratio of men: women is $3: 2$. Multiple myeloma affects the bones, immune system, kidneys and red blood cell count. We report a case of refractory multiple myeloma.
\end{abstract}

Keywords: M band, Pathologic fracture, Plasma cell cancer

showed severe anemia with raised ESR. ESR-120/after 1 hour. Serum Total Protein-7.9gm/dl, Serum Albumin$3.4 \mathrm{gm} / \mathrm{dl} \&$ Serum Globulin-4.4gm/dl with presence of " $\mathrm{M}$ " band. The M band-1.95/dl. Beta 2 microglobulin$5000 \mathrm{mcg} / \mathrm{ml}$. MRI showed myelomatous deposits in the skull. Serum Creatinine was $0.6 \mathrm{mg} / \mathrm{dl}$ and SGPT was 40 $\mathrm{U} / \mathrm{L}$.

After confirming the diagnosis patient was treated with six cycles of C-VAD, Thalidomide ${ }^{3}$ for six cycles along with Dexamethasone ${ }^{4}$ Lenalidomide with Dexamethasone $^{4}$, and Melphalan for symptomatic and curative treatment. She is taking chemotherapy cycles since 6 years. She also had undergone two radiation cycles for the deposition of myeloma at the sacrum \& lumbar region. Recently she also had undergone alphaAnti TNF-Rituximab ${ }^{5}$, Bendamustine, Endoxan chemotherapy along with Dexamethasone for three cycles as she had developed refractory myeloma. She was given injections of Pamidronate/Zolendronate at regular intervals to protect her from pathologic fractures. Along with that she is on herbs, diet control and still continuing the treatment and showing a good fight to the disease.

At present she is on Doxorubicin, Thalidomide ${ }^{6}$ \& Dexamethasone with overall good response to drugs. She is vitally stable \& performing her daily activities. It's been more than 10 years \& 42 chemotherapy cycles for her fighting against myeloma and is setting an example to fight cancer. Her Calcium, Albumin reports are normal \& Beta 2 microglobulin is $2750 \mathrm{mcg} / \mathrm{ml}$.

\section{DISCUSSION \\ DISCUSSION}

On undergoing routine test accidentally was helpful in detecting Myeloma. She had undergone $\mathrm{CBC}$, which
Patient was conscious and oriented, well-nourished and had episodes of fever. No icterus was seen but pallor was . There was no other abnormality in gastrointestinal, respiratory and cardiac system. 
According to a study by the European Cancer Register (2002), only around one third of all multiple myeloma patients live longer than five years. ${ }^{7}$ The patient despite of taking so many chemotherapy cycles and having myeloma since more than 10 years is fighting hard against myeloma with albumin \& calcium levels normal. Newer drugs like Lenalidomide, Rituximab and other drugs along with positive approach in myeloma can prolong life of myeloma patients more than 10 years.

\section{ACKNOWLEDGEMENTS}

The authors are grateful to Dr. S.H. Adwani, Director, Medical Oncology, Jaslok Hospital \& Research Centre, Mumbai and Dr. Anand Parikh, Consultant Pathologist for their precious advice in this case.

\section{REFERENCES}

1. Longo DL. Plasma cell disorders. In: Fauci AS, Braunwald $\mathrm{E}$, Isselbacher $\mathrm{KJ}$, et al, editors. Harrison's Principles of Internal Medicine. 14th Ed. New York: McGraw Hill; 1998:712-3.

2. Küppers R, Klein U, Hansmann ML, Rajewsky K. Cellular origin of human B-cell lymphomas. N Engl J Med 1999; 341:1520-9.

3. Klausner JD, Freedman VH, Kaplan G. Thalidomide as an anti-TNF-alpha inhibitor: implications for clinical use. Clin Immunol Immunopathol 1996; 81:219-23.

4. Alexanian R, Dimopoulos MA, Delasalle K, Barlogie B. Primary dexamethasone treatment of multiple myeloma. Blood 1992; 80:887-90.

5. Quesada JR, Alexanian R, Hawkins M, Barlogie B, Borden E, Itri L, et al. Treatment of multiple myeloma with recombinant alpha-interferon. Blood 1986; 67:275-8.

6. Singhal S, Mehta J, Desikan R, Ayers D, Roberson $\mathrm{P}$, Eddlemon $\mathrm{P}$, et al. Antitumor activity of thalidomide in refractory multiple myeloma. N Engl J Med 1999; 341:1565-71.

7. The EUROCARE-4 database on cancer survival in Europe. Available at http://www.eurocare.it/Results/tabid/79/Default.aspx \#longsurv0002. Accessed 2 August 2012. 